\section{Response of Kentucky Bluegrass (Poa pratensis L.) Cultivars and Selections to Bispyribac-sodium Herbicide}

\author{
Robert R. Shortell ${ }^{1}$, Stephen E. Hart, and Stacy A. Bonos \\ Department of Plant Biology and Pathology, Rutgers, The State University of \\ New Jersey, 59 Dudley Road, New Brunswick, NJ 08901-8520 \\ Additional index words. chlorosis, injury, turfgrass, tolerance, variability
}

\begin{abstract}
Annual bluegrass (Poa annua L.) is a problematic weed in Kentucky bluegrass (Poa pratensis L.). Bispyribac-sodium herbicide can effectively control established annual bluegrass in other cool-season turfgrasses, but unacceptable injury to Kentucky bluegrass has been reported. However, only a few Kentucky bluegrass cultivars have been evaluated. The objective of this study was to determine the extent of intraspecific variability among Kentucky bluegrass cultivars and selections to sequential applications of bispyribac-sodium herbicide. Field experiments were conducted in 2004 and 2005 in New Jersey to determine the response of 55 Kentucky bluegrass cultivars and selections to bispyribac-sodium. The herbicide was applied at $188 \mathrm{~g} \cdot \mathrm{ha}^{-1}$ followed 3 weeks later by a second application of $281 \mathrm{~g} \cdot \mathrm{ha}^{-1}$. Kentucky bluegrass injury ranged from $8 \%$ to $93 \% 8$ weeks after initial treatment (WAIT). 'Blackstone', 'Serene', and A98-962 were the most tolerant to bispyribac-sodium, exhibiting less than $20 \%$ injury 8 WAIT. Conversely, 'Washington', 95AN-10, and 'Avalanche' were the most susceptible with up to $93 \%$ injury 8 WAIT. The range in tolerance to bispyribac-sodium within Kentucky bluegrass indicates the potential for the identification and development of cultivars with improved tolerance to bispyribac-sodium herbicide.
\end{abstract}

Kentucky bluegrass (Poa pratensis L.) is a popular turfgrass species throughout its adaptive range. It typically produces a dense stand of turf with dark green color, high overall turf quality, and a wide range of disease tolerance. This makes it a premier species for lawns, sports fields, and golf courses (Beard, 1973). However, Kentucky bluegrass often becomes infested with annual bluegrass ( $P$. annua L.), especially when maintained at low mowing heights and other stressful environments.

Annual bluegrass is a persistent weed, which reduces overall turfgrass usefulness as a result of to its light green color, high reproductive capacity, and shallow root system (Lush, 1989; Sprague and Burton, 1937). Annual bluegrass tolerates close mowing and germinates rapidly allowing it to outcompete desirable turfgrass species. This is particularly pronounced in Kentucky bluegrass as a result of its slow establishment rate. It can also encroach into stressed Kentucky bluegrass turfs mown at low cutting heights. The poor disease, drought, and wear tolerance of annual bluegrass compared with Kentucky bluegrass (Beard et al., 1978; Lush, 1989) contribute to its decline in quality. Consequently, Kentucky bluegrass infested with

Received for publication 9 July 2008. Accepted for publication 26 Aug. 2008.

New Jersey Experiment Station Publication Number D-12180-01-08.

${ }^{1}$ To whom reprint requests should be addressed; e-mail shortell@eden.rutgers.edu

annual bluegrass requires more water and fungicides, especially in the summer months.

Chemical control options for annual bluegrass in Kentucky bluegrass are limited. Use of pre-emergent herbicides before the annual bluegrass germination cycle can limit infestations from encroaching into Kentucky bluegrass swards but typically have no effect on established annual bluegrass populations. Ethofumesate is a postemergence herbicide that is labeled for annual bluegrass control but often provides inconsistent control with unacceptable Kentucky bluegrass injury (Adams, 1989; Dernoeden and Turner, 1988).

Aside from ethofumesate, there are currently no selective herbicides labeled for control of established annual bluegrass in Kentucky bluegrass. Bispyribac-sodium is a pyrimidinyl carboxy herbicide that controls weeds by inhibiting acetolactate synthase (Shimizu et al., 2002). Bispyribac-sodium has been used for selective postemergence control of barnyardgrass [Echinochloa crusgalli (L.) Beauv.] and other weeds in rice (Oryza sativa L.) (Schmidt et al., 1999; Webster et al., 1999; Williams, 1999) and was recently registered for turf (Anonymous, 2004). Research with bispyribac-sodium indicates applications of 60 to $148 \mathrm{~g} \cdot \mathrm{ha}^{-1}$ can reduce populations of annual bluegrass without injuring creeping bentgrass (Agrostis stolonifera L.) (Askew et al., 2004; Borger and Watschke, 2005; Dernoeden et al., 2004; Lycan et al., 2003; Lycan and Hart, 2005). Additionally, research has found that two applications are needed for complete annual bluegrass control (Lycan and Hart, 2006; McCullough and Hart, 2006; Park et al.,
2002). Limited research with Kentucky bluegrass found a single application of $296 \mathrm{~g} \cdot \mathrm{ha}^{-1}$ on 'Baron' Kentucky bluegrass resulted in $28 \%$ injury 5 weeks after initial treatment (WAIT) (Lycan and Hart, 2005). However, more comprehensive research emphasizing the response of Kentucky bluegrass to multiple applications of bispyribac-sodium is needed.

A significant amount of genetic diversity exists within Kentucky bluegrass. This is attributable in part to the variable ploidy levels and the unique apomictic breeding behavior of the species (Raggi et al., 2006). This reproductive breeding behavior results in many distinct phenotypes and preserves genomic complexity through the inhibition of outcrossing. Many examples of this complexity can be found in the literature, including differences in agronomic and morphological traits (Bonos et al., 2000; Shortell et al., 2006), summer stress tolerance (Bonos and Murphy, 1999), both drought and heat tolerance (Wang and Huang, 2004), and disease tolerance (Bonos et al., 2000, 2006; Czembor, 2003; Czembor et al., 2001). The objective of this study was to determine the amount of intraspecific variability of Kentucky bluegrass cultivars and experimental selections to sequential applications of bispyribac-sodium herbicide.

\section{Materials and Methods}

This experiment was conducted in 2004 and 2005 at the Rutgers Plant Biology and Pathology Research and Extension Farm in Adelphia, NJ. The soil type was a Freehold sandy-loam (fine-loamy, mixed, active, mesic Aquic Hapludult) with a $\mathrm{pH}$ of 6.4 and $2.0 \%$ organic matter. Separate Kentucky bluegrass cultivar trials were established in the fall of 2000 and 2001. Entries in each test were sown by hand using a maximum of $15 \mathrm{~g}$ of seed per $0.9 \times 1.5-\mathrm{m}$ plot $\left(10 \mathrm{~g} \cdot \mathrm{m}^{-2}\right)$. An unplanted $15-\mathrm{cm}$ border was left around each plot. Kentucky bluegrass cultivars and selections were arranged in a randomized complete block design with three replications in each trial. Fifty-five cultivars or experimental selections were replicated in both trials. These entries represent a broad range of diversity within Kentucky bluegrass and contain cultivars within the major classification types (Bonos et al., 2000). The trials were maintained at $3.8 \mathrm{~cm}$ and mowed twice weekly with a reel mower (Toro, Bloomington, MN) with clippings returned. The turf trials received $98 \mathrm{~kg} \cdot \mathrm{ha}^{-1} \mathrm{~N}$ per year applied in four applications of $25 \mathrm{~kg} \cdot \mathrm{ha}^{-1} \mathrm{~N}$. The plots were irrigated only to prevent drought stress.

Bispyribac-sodium treatments (Velocity ${ }^{\circledR}, 80 \mathrm{WP}$ herbicide; Valent U.S.A. Corp., Walnut Creek, CA) were applied in the early summer of 2004 and 2005 to mimic the conditions of highest annual bluegrass activity seen in previous studies (Lycan and Hart, 2006). Half of each plot was treated with bispyribac-sodium and the other half was left untreated as a control. The Kentucky bluegrass trial seeded in 2001 was treated with 
$188 \mathrm{~g} \cdot \mathrm{ha}^{-1}$ on 14 June 2004 followed by $281 \mathrm{~g} \cdot \mathrm{ha}^{-1}$ on 7 July 2004 (3 WAIT). The Kentucky bluegrass trial seeded in 2000 was treated with $188 \mathrm{~g} \cdot \mathrm{ha}^{-1}$ on 9 June 2005 followed by $281 \mathrm{~g} \cdot \mathrm{ha}^{-1}$ on 30 June 2005 (3 WAIT). Although lower rates do provide adequate annual bluegrass control, higher rates were used in this study to help achieve maximum cultivar differentiation to bispyribac-sodium and to determine maximum cultivar susceptibilities. Treatments were applied with a single-nozzle $\mathrm{CO}_{2}$ backpack sprayer equipped with a 9504E nozzle tip (Tee Jet $^{\circledR}$ flat fan nozzles; Spraying Systems Co., Wheaton, IL), which delivered $374 \mathrm{~L} \cdot \mathrm{ha}^{-1}$ of spray solution at $221 \mathrm{kPa}$. Turfgrass injury was visually assessed as the amount of injury observed on the treated half of each plot directly compared with its adjacent untreated control and reported on a $0 \%$ to $100 \%$ scale with 0 representing no injury and 100 representing complete necrosis. Cultivars and selections were evaluated at 2, 4, and 8 WAIT.

Data were tested for normality using the univariate procedure of the Statistical Analysis System (SAS) V.8.2 (SAS Institute, Cary, NC). These data did not show significant deviation from normality and were therefore directly subjected to the analysis of variance for a randomized complete block design. Differences in mean visual injury between cultivars were determined using Fisher's protected least significant difference test at the $P=0.05$ level.

\section{Results and Discussion}

The analysis of variance for injury ratings taken at 2, 4, and 8 WAIT are presented in Table 1. There was no significant cultivar-byyear interaction for any of the rating dates; therefore, results from 2004 and 2005 were combined (Table 2). The fact that there was no interaction between years and relatively similar results were observed for each cultivar in each year indicates that this trait is under strong genetic control and not highly affected by the fluctuating environmental conditions. Significant differences in injury to bispyribacsodium between cultivars and selections were observed at 4 and 8 WAIT (Table 1).

Bispyribac-sodium typically causes a transitory chlorosis that starts in tolerant grasses such as creeping bentgrass (Agrostis

Table 1. Calculated mean squares of percent injury ratings at 2,4 , and 8 weeks after initial treatment from analysis of variance of bispyribac-sodium tolerance of 55 Kentucky bluegrass cultivars and selections.

\begin{tabular}{|c|c|c|c|c|}
\hline \multirow{2}{*}{ Source of variance } & df & Week 2 & Week 4 & Week 8 \\
\hline & \multirow{2}{*}{\multicolumn{4}{|c|}{ 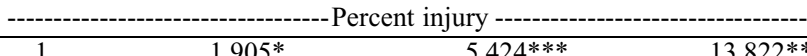 }} \\
\hline$\overline{\text { Year }}$ & 1 & & & $13,822 * *$ \\
\hline Cultivar & 54 & 586 & $473 * *$ & $1,885^{*}$ \\
\hline Rep (year) & 4 & 700 & $1,544 * *$ & $3,938^{*}$ \\
\hline Cultivar $\times$ year & 54 & 232 & 141 & 615 \\
\hline Cultivar $\times$ rep & 108 & 119 & 86 & 283 \\
\hline Error & 216 & 101 & 72 & 280 \\
\hline
\end{tabular}

${ }^{2}$ Bispyribac-sodium treatments were applied as $188 \mathrm{~g} \cdot \mathrm{ha}^{-1}$ on either 14 June 2004 or 9 June 2005 followed by a sequential application of $281 \mathrm{~g} \cdot \mathrm{ha}^{-1} 3$ weeks after the initial treatment (7 July 2004 or 30 June 2005, respectively).

${ }^{*, * *, * * *}$ Significant $\mathrm{F}$ tests at $P=0.05,0.01$, and 0.001 , respectively.
The majority of the cultivars evaluated in this study displayed intermediate tolerance to bispyribac-sodium with injury levels ranging from $30 \%$ to $70 \% 8$ WAIT. Kentucky bluegrass cultivars Livingston and Midnight are good examples of this level of tolerance with 'Livingston' exhibiting 52\% injury 8 WAIT, and 'Midnight' showing 35\% injury 8 WAIT. Other cultivars exhibiting an intermediate level of injury, included 'SR 2284' and 'Liberator' with 35 and $38 \%$ injury 8 WAIT, respectively.

In both years, Kentucky bluegrass cultivars responded to bispyribac-sodium in three relatively distinct consistent patterns. Although all of the cultivars were initially injured, some such as Blackstone and Serene recovered rapidly from initial chlorosis and suffered little to no decline in turfgrass stand. The majority of the cultivars such as Midnight and Livingston did not recover rapidly from initial chlorosis exhibited some necrosis of the leaf tissue and slight thinning of the turfgrass stand. Lastly, several cultivars such as Avalanche, Washington, North Star, and Champagne did not recover from chlorosis, exhibited significant desiccation of the leaf tissue, and suffered nearly complete turfgrass stand loss at 8 WAIT.

Bispyribac-sodium herbicide has been shown to be highly effective at removing populations of annual bluegrass from agricultural commodities, including rice (Oryza sativa), and some cool-season turfgrasses (Lycan and Hart, 2006; Schmidt et al., 1999; Webster et al., 1999; Williams, 1999). As hypothesized, a wide range of injury in response to bispyribac-sodium was observed in this study. Although injury levels observed in this study on most Kentucky bluegrass cultivars may be considered unacceptable to turfgrass managers, some tolerant Kentucky bluegrass cultivars and experimental selections had the ability to recover from multiple applications of bispyribac-sodium at higher than labeled use rates for annual bluegrass control and showed acceptable turf quality within 8 weeks. Thus, tolerant cultivars should be evaluated for tolerance to bispyribacsodium applied at lower rates that are effective for annual bluegrass control. The consistent results between years and large variation between entries provide evidence that this trait is genetically controlled. This indicates that the relative response of these cultivars and selections to bispyribac-sodium should be consistent over multiple locations with different environments (Poehlman and Sleper, 1995). These results indicate the potential to identify current cultivars and develop new cultivars of Kentucky bluegrass with acceptable tolerance to bispyribac-sodium.

In conclusion, high rates of bispyribacsodium were able to significantly differentiate Kentucky bluegrass cultivars and selections for tolerance to bispyribac-sodium. Kentucky bluegrass cultivars and selections were identified that exhibited very little injury in response to bispyribac-sodium. The apomictic breeding behavior of Kentucky bluegrass allows for the ability to fix traits 
Table 2. Percent injury of 55 Kentucky bluegrass cultivars and selections evaluated in 2004 and 2005 at Adelphia, NJ.,y

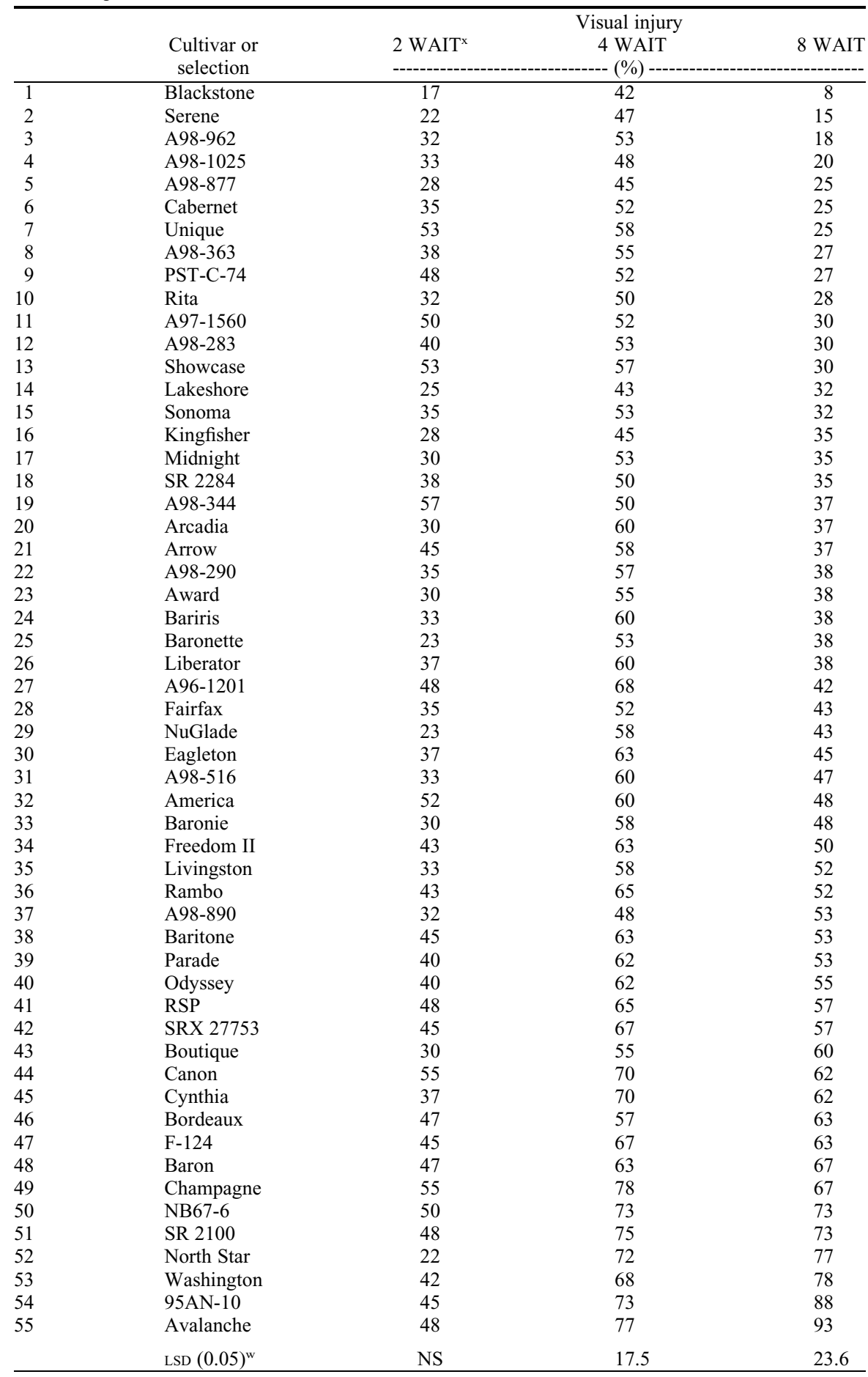

$\overline{{ }^{2} \text { Entries are ranked by order of tolerance to bispyribac-sodium }{ }^{y} \text { herbicide } 8 \text { weeks after initial treatment. }}$ ${ }^{y}$ Bispyribac-sodium was applied at 188 followed by $281 \mathrm{~g} \cdot \mathrm{ha}^{-1} 3$ WAIT. Application dates were 14 June and 7 July 2004 and 9 June and 30 June 2005.

${ }^{\mathrm{x}} \mathrm{WAIT}=$ weeks after initial treatment.

${ }^{\mathrm{w}}$ LSD $(0.05)=$ Fisher's protected least significant difference at a $5 \%$ probability level.

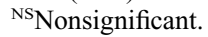

within a cultivar and provides stable inheritance through successive generations. This suggests that the identification and development of Kentucky bluegrass cultivars with improved tolerance to bispyribac-sodium is possible. Within these tolerant cultivars and selections, bispyribac-sodium could be used as a new tool for annual bluegrass control provided a period of aesthetic turfgrass injury can be tolerated.

\section{Literature Cited}

Adams, J.C. 1989. Control of Poa апnиа in the United States in cool-season turf with ethofumesate, p. 323-324. In: Takatoh, H. (ed.). Proc. Sixth Intern. Turfgrass Res. Conf., Tokyo, Japan.

Anonymous. 2004. Velocity ${ }^{\circledR}$ herbicide label. Valent U.S.A. Corporation, Walnut Creek, CA.

Askew, S.D., J.B. Beam, D.S. McCall, W.L. Barker, H.B. Couch, and J.R. Chamberlin. 2004. Annual bluegrass, roughstalk bluegrass, and dollar spot control with bispyribac-sodium. Proc. Northeast. Weed Sci. Soc. 58:124 126.

Beard, J.B. 1973. Cool season turfgrasses, p. 54-131. In: Turfgrass: Science and Culture. PrenticeHall, Englewood Cliffs, NJ.

Beard, J.B., P.E. Rieke, A.J. Turgeon, and J.M. Vargas. 1978. Annual bluegrass (Poа аппиа L.) description, adaptation, culture and control. Res. Rep. 352. Michigan State Univ. Agr. Exp. Stn., East Lansing, MI.

Bonos, S.A., B.B. Clarke, and W.A. Meyer. 2006 Breeding for disease resistance in the major cool-season turfgrasses. Annu. Rev. Phytopathol. 44:213-234.

Bonos, S.A., W.A. Meyer, and J.A. Murphy. 2000. Classification of Kentucky bluegrass genotypes grown as spaced-plants. HortScience 35:910 913.

Bonos, S.A. and J.A. Murphy. 1999. Growth responses and performance of Kentucky bluegrass under summer stress. Crop Sci. 39:770774.

Borger, J.B. and T.L. Watschke. 2005. Annual bluegrass control and more. Proc. Northeast. Weed Sci. Soc. 59:84.

Czembor, E. 2003. Resistance of Kentucky bluegrass (Poa pratensis L.) ecotypes from Polish gene bank to melting out (Drechslera poae) under field conditions in 1998-2000. Genet. Resour. Crop Evol. 50:747-756.

Czembor, E., U. Feuerstein, and G. Zurek. 2001. Preliminary observations on resistance to rust diseases of Kentucky bluegrass ecotypes from Poland. J. Phytopathol. 149:2-83.

Dernoeden, P.H., J.E. Kaminski, and S.J. McDonald 2004. Preemergence smooth crabgrass and postemergence annual bluegrass control in turf grass. Proc. Northeast. Weed Sci. Soc. 58:119120

Dernoeden, P.H. and T.R. Turner. 1988. Annual bluegrass control and tolerance of Kentucky bluegrass and perennial ryegrass to ethofumesate. HortScience 23:565-567.

Lush, W.M. 1989. Adaptation and differentiation of golf course populations of annual bluegrass. Weed Sci. 37:54-59.

Lycan, D.W. and S.E. Hart. 2005. Cool-season turfgrass response to bispyribac-sodium. HortScience 40:1552-1555.

Lycan, D.W. and S.E. Hart. 2006. Seasonal effects on annual bluegrass control in creeping bentgrass with bispyribac-sodium. Weed Technol. 20:722-727.

Lycan, D.W., S.E. Hart, and J. Fausey. 2003. Potential use of V-10029 for weed control in cool-season turf grass. Proc. Northeast. Weed Sci. Soc. 57:96.

McCullough, P.E. and S.E. Hart. 2006. Temperature influences creeping bentgrass (Agrostis stolonifera L.) and annual bluegrass (Poa annua L.) responses to bispyribac-sodium. Weed Technol. 20:728-732.

Park, N., Y. Suto, Y. Miura, N. Nakatani, S. Iori, and M. Ogasawara. 2002. Annual bluegrass (Poa annua L.) control in bentgrass (Agrostis palustris Huds.) greens with sequential application of bispyribac-sodium combined with dinitroanalines. Weed Biol. Mgt. 2:159162.

HortScience Vol. 43(7) December 2008 
Poehlman, J. and D. Sleper. 1995. Quantitative inheritance in plant breeding, p. 60-82. In: Breeding field crops. 4th Ed. Iowa State Press, Ames, IA.

Raggi, L., E. Albertini, G. Marconi, T. Sharbel, and M. Falcinelli. 2006. Genetic and reproductive diversity within and among Kentucky bluegrass (Poa pratensis L.) worldwide accessions. Proc. It. Soc. Agr. Gen. 50:23.

Schmidt, R.E., F.L. Talbert, J.S. Baldwin, E.F. Rutledge, E.F. Scherder, and C.C. Wheeler. 1999. Performance of V-10029 (bispyribacsodium) in rice weed control programs. Proc. South. Weed Sci. Soc. 52:49-50.
Shimizu, T., I. Nakayama, K. Nagayama, T. Miyazawa, and Y. Nezu. 2002. Acetolactate synthase inhibitors, p. 1-41. In: Böger, P., K. Wakabayashi, and K. Hirai (eds.). Herbicide classes in development: Mode of action, targets, genetic engineering, chemistry. SpringerVerlag, New York, NY.

Shortell, R.R., W.A. Meyer, and S.A. Bonos. 2006 Morphological characteristics of Kentucky bluegrass cultivars and selections in New Jersey. 2005 Rutgers Turfgrass Proc. 37:183-192.

Sprague, H.B. and G.W. Burton. 1937. Annua bluegrass (Poa annua L.), and its requirements for growth, p. 1-24. In: New Jersey Agr.
Experiment Station Bulletin 630. New Brunswick, NJ.

Wang, Z. and B. Huang. 2004. Physiological recovery of Kentucky bluegrass from simultaneous drought and heat stress. Crop Sci. 44: 1729-1736.

Webster, E.P., W. Zhang, D.Y. Lanclos, J.A. Masson, and S.N. Morris. 1999. Experimenta herbicides for weed control in rice. Proc. South. Weed Sci. Soc. 52:16-17.

Williams, B.J. 1999. Barnyardgrass (Echinochloa crus-galli) control in dry-seeded rice with V-10029. Proc. South. Weed Sci. Soc. 52: 50 . 